\title{
PENGARUH MUTU PELAYANAN RAWAT JALAN TERHADAP PERSEPSI PASIEN/KELUARGA DI RS MISI LEBAK BANTEN
}

\author{
Sarma Eko Natalia Sinaga \\ Akademi Keperawatan Yatna Yuana Lebak Banten
}

\begin{abstract}
Quality of health services for patients is a sense of satisfaction with the health services received. Where the good quality is associated with recovery from illness, improvement of health status, good health service, physical facility, official friendliness, easy procedure and reasonable cost. The purpose of this study illustrates the effect of quality of outpatient services (age, responsiveness, tangibles) on patient and family perception at the RS Lebak Mission. The study design is descriptive with cross-sectional approach, in which a large sample of 110 respondents that are outpatients that have received health services. The independent variables in this study are age, responsiveness, tangibles while the dependent variable is the perception of patient and family. The Data collection is using questioners and the data analysis used univariate analysis and bivariat ChiSquare Test. From the statistical test obtained results that there is a relationship between responsiveness to the quality of outpatient services $(\mathrm{P}=0.000)$. The relationship between tangibles to the quality of outpatient services $(\mathrm{P}=0.000)$. Hospitals should be able to provide physical facilities, the provision of the best care equipment, maintaining the cleanliness and neatness of the room in hospital. In addition, health workers should have the desire to provide the best assistance to patients.
\end{abstract}

\section{Keywords: Level of Satisfaction, Perception, Service Quality}

\section{PENDAHULUAN}

Mutu pelayanan kesehatan adalah pengguna pelayanan kesehatan yang merasa puas terhadap pelayanan kesehatan yang diberikan dan tingkat kepuasan tersebut yang dialami oleh rata-rata penduduk serta pemberi pelayanan kesehatan sesuai dengan pedoman dan kode etik profesi (Satrianegara, 2009).

Potter \& Perry (2007), menyatakan bahwa pengguna pelayanan kesehatan sekarang sudah memiliki pengetahuan dan perhatian yang cukup baik terhadap isu kesehatan dan juga tentang kualitas keperawatan, rumah sakit dan dokter. Pengalaman pasien menggunakan pelayanan kesehatan merupakan tolak ukuran kualitas suatu rumah sakit, walaupun rumah sakit tersebut memiliki tingkat teknologi yang tinggi.

Cara pandang masyarakat terhadap penilaian dan pemilihan pelayanan kesehatan berubah karena persaingan bisnis rumah sakit yang sangat kompetitif. Rumah Sakit dituntut untuk lebih memperhatikan kepuasan pasien dan peningkatan mutu pelayanan baik pasien rawat inap maupun rawat jalan. Oleh karena itu Rumah Sakit harus meningkatkan kualitas pelayanannya dengan memanfaatkan sumber daya yang ada. Seiring waktu rumah sakit yang tidak berkualitas akan tergerus oleh persaingan bisnis rumah sakit yang sangat sengit (Gultom, Jenny., 2008).

Menurut Tjiptono (2008), salah satu cara untuk memenangkan persaingan bisnis Rumah Sakit adalah dengan mengupayakan peningkatan mutu pelayanan kesehatan yang berkelanjutan (Continuous Quality Management) dan memberikan kepuasan terhadap pasien dan keluarganya. Konsep SerQual yang digunakan dalam penilaian pelayanan kesehatan menurut Parasuraman (1990) adalah: reliability, responsiveness, assurance, empathy, tangibles Sedangkan dalam penelitian ini hanya dibahas tentang responsiveness dan tangibles. Responsiveness (daya tanggap) keinginan untuk memberikan bantuan dan pelayanan kepada pengguna layanan kesehatan dengan baik. Dengan adanya indikator responsiveness memungkinkan tingkat kepuasan pelayanan kesehatan yang dirasakan oleh konsumen semakin meningkat dan dapat tercapai. Tangibles (bukti fisik) meliputi tampilan kerja perawat yang terampil, kebersihan dan kerapian ruangan, peralatan perawatan dan komunikasi yang tersedia dan fasilitas fisik. Data penelusuran yang didapatkan peneliti dari masyarakat sekitar RS Misi Lebak yang pernah dilayani di poliklinik RS Misi Lebak mengatakan merasa puas dengan pelayanan yang telah diterima, dan 
menurut mereka, lingkungan Rumah Sakit pun sudah cukup bersih. Tetapi yang menjadi kendala adalah lahan parkir yang terlalu sempit sehingga menyulitkan keluarga pasien untuk parkir, oleh karena itu banyak pengunjung Rumah Sakit yang harus menggunakan sisi jalan raya yang akhirnya dapat menyebabkan kemacetan. Berdasarkan uraian di atas peneliti ingin mengkaji pengaruh mutu pelayanan rawat jalan terhadap kepuasan pasien/keluarga di RS Misi Lebak.

\section{METODE PENELITIAN}

\section{Jenis Penelitian}

Penelitian yang digunakan adalah penelitian deskriptif dengan pendekatan cross-sectional.

\section{Waktu dan Tempat Penelitian}

Penelitian ini dilakukan pada bulan Juli 2017 di RS Misi Lebak Banten

\section{Sampel}

Besar sampel yang diambil adalah 110 responden yang merupakan pasien rawat jalan yang telah mendapatkan layanan kesehatan.

\section{Pengumpulan dan Analisis Data}

Pengumpulan data dengan menggunakan kuesioner dan observasi. Analisa data yang digunakan adalah analisa Univariat dan Bivariat dengan Uji Chi-Square.

\section{HASIL DAN PEMBAHASAN}

Dari hasil penelitian ini didapatkan persepsi pasien yang baik terhadap kualitas pelayanan rawat jalan di RS Misi Lebak sebesar $21(19.1 \%)$. Dari segi umur, sebagian besar pasien berumur $<43$ tahun sebesar $56(50.9 \%)$, berumur $\geq 43$ tahun sebesar 54 (49.1\%). Pasien dengan responsiveness baik sebesar 33 (30.0\%), responsiveness kurang baik sebesar 77 (70.0\%). Pasien dengan tangibles baik sebesar 27 (24.5\%), tangibles kurang baik sebesar 83 $(75.5 \%)$.

Pasien yang berumur $<43$ tahun yang memiliki persepsi baik terhadap mutu pelayanan rawat jalan ada sebanyak 13 $(23.2 \%)$, sedangkan pasien yang berumur $\geq 43$ tahun yang memiliki persepsi baik terhadap mutu pelayanan rawat jalan ada sebanyak 8 $(14.8 \%)$. Hasil uji statistik diperoleh nilai $\mathrm{p}=0.380$, maka dapat disimpulkan tidak ada hubungan yang signifikan antara umur dengan persepsi terhadap mutu pelayanan rawat jalan.
Sesuai dengan penelitian Manurung, Lidya (2010) dimana tidak ada hubungan usia dengan tingkat kepuasan terhadap pelayanan kesehatan $\mathrm{p}=0.300$.

Menurut Liliweri (2007), orang dewasa lebih memiliki pemikiran dan pandangan yang lebih rasional dibanding anak yang berusia lebih muda. Disini terdapat perbedaan antara hasil penelitian dan ahli, namun demikian menurut Notoatmodjo (2003), ketika orang dewasa yang sudah memiliki pemikiran/ persepsi tentang sesuatu hal yang sudah dianut selama bertahun-tahun memungkinkan orang dewasa menjadi sulit menerima hal-hal yang baru.

Tabel 1. Distribusi Responden berdasarkan Variabel Umur, Responsiveness, Tangibles dan Persepsi

\begin{tabular}{lcc}
\hline \multicolumn{1}{c}{ Variabel } & Frekuensi & \% \\
\hline Umur & & \\
$\quad<43$ tahun & 56 & 50.9 \\
$\geq 43$ tahun & 54 & 49.1 \\
\hline Responsiveness & & \\
(Daya Tanggap) & & \\
$\quad$ Kurang Baik & 77 & 70.0 \\
$\quad$ Baik & 33 & 30.0 \\
\hline Tangibles & & \\
(Bukti Fisik) & & \\
$\quad$ Kurang Baik & 83 & 75.5 \\
$\quad$ Baik & 27 & 24.5 \\
\hline Persepsi & & \\
$\quad$ Kurang Baik & 89 & 80.9 \\
Baik & 21 & 19.1 \\
\hline
\end{tabular}

Ada sebanyak 7 (9.1\%) pasien yang mendapatkan responsiveness kurang baik memiliki persepsi baik terhadap mutu pelayanan rawat jalan. Sedangkan diantara pasien yang mendapatkan responsiveness baik, ada $14(42.4 \%)$ yang memiliki persepsi baik terhadap mutu pelayanan rawat jalan. Hasil uji statistik diperoleh nilai $\mathrm{p}=0.000$, maka dapat disimpulkan ada hubungan yang signifikan antara responsiveness dengan persepsi terhadap mutu pelayanan rawat jalan. Penelitian Agus Sufron (2008) juga menunjukkan ada hubungan antara persepsi pasien tentang responsiveness dengan tingkat kepuasan pasien rawat jalan di Puskesmas Penumping $\mathrm{p}=0.001$. Menurut Parasuraman et.al. (1990), responsiveness adalah keinginan untuk memberikan bantuan 
dan pelayanan kepada pengguna layanan kesehatan dengan baik. Dengan adanya indikator responsiveness memungkinkan tingkat kepuasan pelayanan kesehatan yang dirasakan oleh konsumen semakin meningkat dan dapat tercapai. Dengan penjelasan di atas dapat disimpulkan bahwa ketika pemberi layanan kesehatan bersedia menolong dan memberi kepuasan bagi pelanggan maka tingkat kepuasan daripada pelanggan semakin meningkat.

Tabel 2. Pengaruh Mutu Pelayanan Rawat Jalan terhadap Persepsi Pasien/Keluarga di RS Misi Lebak Banten

\begin{tabular}{llcccccc}
\hline \multirow{2}{*}{ Variabel } & \multicolumn{5}{c}{ Persepsi Pasien } & & \multirow{2}{*}{ OR } \\
\cline { 2 - 6 } & & Kurang Baik & \multicolumn{2}{c}{ Baik } & P Value & \multirow{2}{*}{ OR } \\
\cline { 2 - 6 } & $<43$ tahun & 43 & 76.8 & 13 & 23.2 & \multirow{2}{*}{0.380} & 0.575 \\
\hline \multirow{2}{*}{ Umur } & $\geq 43$ tahun & 46 & 85.2 & 8 & 14.8 & & $0.2-1.5$ \\
\hline Responsiveness & Kurang Baik & 70 & 90.9 & 7 & 9.1 & \multirow{2}{*}{0.000} & 7.368 \\
(Daya Tanggap) & Baik & 19 & 57.6 & 14 & 42.4 & & $2.6-20.8$ \\
\hline Tangibles & Kurang Baik & 76 & 91.6 & 7 & 8.4 & \multirow{2}{*}{0.000} & 11.692 \\
(Bukti Fisik) & Baik & 13 & 48.1 & 14 & 19.1 & & $3.9-34.4$ \\
\hline
\end{tabular}

Ada sebanyak $7(8.4 \%)$ pasien yang mendapatkan tangibles kurang baik memiliki persepsi baik terhadap mutu pelayanan rawat jalan. Sedangkan diantara pasien yang mendapatkan tangibles baik, ada $14(19.1 \%)$ yang memiliki persepsi baik terhadap mutu pelayanan rawat jalan. Hasil uji statistik diperoleh nilai $\mathrm{p}=0.000$, maka dapat disimpulkan ada hubungan yang signifikan antara tangibles dengan persepsi terhadap mutu pelayanan rawat jalan. Menurut penelitian Rini Harjanti (2012), ada hubungan antara tangibles dengan persepsi tentang mutu pelayanan rawat jalan $\mathrm{p}=0.001$. Menurut Parasuraman et.al (1990), tangibles meliputi tampilan kerja perawat yang terampil, kebersihan dan kerapian ruangan, peralatan perawatan dan komunikasi yang tersedia dan fasilitas fisik. Hal ini diperkuat dengan pendapat Maslina (2011) yang menyatakan bahwa persepsi pasien terhadap tangibles membawa pengaruh pada kepuasan setelah mendapatkan pelayanan rawat jalan di Rumah Sakit.

\section{KESIMPULAN DAN SARAN}

Pada penelitian ini jumlah sampel yang diambil sebanyak 110 responden yang dilakukan pada pasien rawat jalan RS Misi Lebak. Dari hasil uji statistika didapatkan ada hubungan antara responsiveness dengan persepsi terhadap mutu pelayanan rawat jalan $(\mathrm{P}=0.000)$. Terdapat hubungan antara tangibles dengan persepsi terhadap mutu pelayanan rawat jalan $(\mathrm{P}=0.000)$.

Rumah Sakit harus memiliki petugas kesehatan yang terampil, berupaya meningkatkan kebersihan, kerapian ruangan, ketersediaan peralatan perawatan dan fasilitas fisik. Demikian juga dengan seluruh petugas kesehatan rawat jalan yang langsung berhubungan dengan pasien agar meningkatkan pelayanan dengan cara bersedia memberi bantuan dan pelayanan yang terbaik. Hal tersebut bertujuan untuk meningkatkan kepuasan pasien/keluarga terhadap pelayanan rawat jalan Rumah Sakit.

\section{DAFTAR PUSTAKA}

Agus Sufron dan Supratman (2008). Analisis Hubungan Persepsi Pasien tentang Mutu Pelayanan Kesehatan dengan Tingkat Kepuasan Pasien Di Puskesmas Penumping Kota Surakarta. Jurnal: Berita Ilmu Keperawatan. ISSN 19792697, Vol. 1 No. 3, September 2008:119124.

Gultom, Jenny (2008). Analisis Kepuasan Pasien terhadap Pelayanan Rawat Jalan di Poliklinik Rumah Sakit Azra Tahun 2008. Skripsi: FKM UI

Liliweri, Alo. (2007). Dasar-dasar Komunikasi Kesehatan. Yogyakarta: Pustaka Pelajar

Manurung, Lidya (2010). Analisis Hubungan Tingkat Kepuasan Pasien Rawat Jalan 
terhadap Pelayanan Instalasi Farmasi dengan Minat Pasien Menebus Kembali Resep Obat di Instalasi Farmasi RSUD Budhi Asih. Tesis: FKM UI.

Maslina, Vina Hotnurayda (2011). Hubungan Persepsi Pasien tentang Kualitas Pelayanan dengan Minat Kunjungan Ulang Pasien Rawat Jalan di RS Zahira Jakarta. Skripsi: FKM UI.

Notoatmodjo, Soekidjo, (2003). Pendidikan dan Perilaku Kesehatan. Jakarta : Rineka Cipta.

Parasuraman, A., Zeithml, V.A., Beny, L.L (1990). Delivery Quality Service: Balancing Costumer Perception and Expectation. New York: The Press.
Potter, AP \& Perry, GA. (2007). Fundamental of Nursing: Concept, Proccess \& Practice. St Louis: Mosby Year Book.

Rini Harjanti (2012). Persepsi Pasien terhadap Mutu Pelayanan Rawat Jalan di Rumah Sakit Graha Permata Ibu. Skripsi : FKM UI.

Satrianegara MF, S.S. (2009), Buku Ajar Organisasi dan Manajemen Pelayanan Kesehatan Serta Kebidanan. Salemba Medika. Jakarta.

Tjiptono, F. (2008). Servive Management Mewujudkan Layanan Prima. Yogyakarta: Andi 